\title{
Transformasi Ruang Perkotaan di Permukiman Nelayan (Studi Kasus: Tambakmulyo, Semarang)
}

\author{
The Transformation of Urban Space in Fisherman Settlement \\ (Case Study: Tambak Mulyo Semarang)
}

\section{Bambang Setioko ${ }^{1}$}

Diterima : 16 Mei 2013

Disetujui: 9 Juli 2013

\begin{abstract}
Abstrak: Pada umumnya permukiman nelayan secara fisik berbeda dengan permukiman perkotaan, karena mempunyai keunikan yang mencerminkan tradisi dan kulturnya penghuninya. Hal ini terdapat pada kawasan permukiman nelayan Tambak Mulyo di Kawasan Pantai Kota Semarang, yang ditunjukkan dari hasil pengamatan berkala yang dilakukan terhadap kawasan tersebut. Bentukan ruang perkotaan secara visual mirip dengan yang ada di perkampungan kota. Kegiatan khas nelayan tidak lagi terlihat dominan. Hal ini mengakibatkan citra sebagai kawasan permukiman nelayan di kawasan tersebut semakin pudar. Tujuan penelitian ini adalah untuk mendapatkan pemahaman yang mendalam tentang fenomena transformasi ruang perkotaan di permukiman nelayan, dengan studi kasus di kawasan permukiman nelayan Tambak Mulyo, di Kawasan Pantai Kota Semarang. Penelitian ini menggunakan pendekatan deduktif - rationalistik. Sedangkan metode penelitian yang digunakan untuk mengungkap fenomena tranformasi pola ruang perkotaan tersebut adalah metoda penelitian deskriptif-kualitatif. Berdasar pada analisa bentuk fisik dan observasi sosio spasialnya transformasi ruang perkotaan telah terjadi, penelitian ini berhasil mengungkap fenomena transformasi ruang perkotaan dari semula berorientasi ke arah laut, telah berubah ke arah daratan.
\end{abstract}

Kata kunci: transformasi, ruang perkotaan, orientasi, sosio spasial.

Abstract: Fisherman settlements are physically different to common urban settlements, because it has a uniqueness reflect to their tradition and culture. Some periodical observation has been made in Tambakmulyo fisherman settlement-Semarang shown different phenomena, which the fisherman's urban space has visual similarity to the common open space. The settlement image has been melting away because of some unique activities has been less dominant conducted. This research has a purpose to get more understanding about the urban space transformation in both physical and socio-spatial point of views, while deductive-rationalistic approach also have been used to support research objectives. In addition, a descriptive-qualitative method has been proposed in order to reveal the urban space transformation phenomena. The urban space transformation in the fisherman settlements has been occurred, based on the physical form analysis and socio-spatial observation. Furthermore, this study has been successfully finding the urban space transformation phenomena, from the sea oriented toward the mainland, which is the fisherman unique activities are no longer dominated their urban space.

Keywords: transformation, urban space, orientation, socio-spatial.

\footnotetext{
${ }^{1}$ Jurusan Arsitektur Fakultas Teknik Universitas Diponegoro J1. Prof. Soedharto, SH - Tembalang, Semarang, 50275
}

Korespondensi: keliek2000@yahoo.com 


\section{Pendahuluan}

Permukiman nelayan di kawasan perkotaan secara fisik berbeda dengan permukiman perkotaan pada umumnya, karena mempunyai ke unikan, baik dilihat dari aspek fisik visual, lokasi maupun kegiatan masyarakat yang berlangsung di ruang perkotaan, sebagai cerminan tradisi dan kulturnya. Di banyak kota di negara maju, keunikan khas permukiman nelayan yang telah berumur puluhan tahun dilestarikan, sehingga mampu membentuk citra kawasan dan tumbuh menjadi ikon wisata. Pengamatan yang dilakukan secara berkala terhadap permukiman nelayan Tambakmulyo (dahulu bernama Tambaklorok), di kawasan pantai Kota Semarang pada beberapa dekade belakangan ini menunjukkan fenomena yang berbeda. Kawasan tersebut secara fisik visual hampir mirip dengan perkampungan kota pada umumnya. Kegiatan khas nelayan yang dilakukan oleh entitas nelayan yang berlangsung di urban space (ruang perkotaan) tidak lagi terlihat dominan. Hal ini mengakibatkan citranya sebagai kawasan permukiman nelayan yang sudah ada sejak tahun 1950-an dirasakan semakin pudar.

Pengertian ruang perkotaan dalam penelitian ini adalah ruang yang mempunyai makna dalam mewadahi kegiatan masyarakatnya yang mencerminkan adat dan kebiasaanya. Pengertian ini berbeda artinya dengan pengertian "ruang di dalam area kota" yang dapat berujud super hole (lobang besar) bekas proyek peremajaan kota (Shirvani, 1985). Dalam memahami konsep ruang perkotaan, harus dikaitkan dengan aspek estetika dan pemaknaanya (Krier, 1991; Gür, 2007). Jika hal itu tidak dilakukan pemahaman ruang perkotaan bisa terjebak dengan mengartikannya sebagai semua ruang di area kota termasuk lahan kosong antar bangunan yang banyak kita jumpai di kota kota pada umumnya. Merujuk pada pengertian tentang ruang perkotan seperti tersebut diatas, dapat dipahami bahwa ruang perkotaan pada umumnya menyatu dan merupakan bagian integral dengan bentukan permukimannya karena masing masing saling berpengaruh sehingga perkembangannya tidak boleh dilihat secara fragmentaris (Zahnd, 1999).

\section{Lokus Penelitian}

Penelitian ini dilakukan di kawasan permukiman nelayan di wilayah pantai Kota Semarang. Secara administratif Kota Semarang terbagi menjadi 16 wilayah kecamatan dan 117 kelurahan. Luas wilayah administratifnya tercatat 373, $70 \mathrm{Km} 2$ (Bappeda Kota Semarang, 2012). Permukiman nelayan Tambakmulyo terletak di Kelurahan Tanjung Mas, Kecamatan Semarang Utara (lihat Gambar 1). Pada awal terbentuknya, kawasan permukiman nelayan ini dibatasi oleh dua sungai yang mengalir sejajar ke arah Utara menuju Laut Jawa. Di sisi Barat mengalir Kali Banger dan dan di sisi Timur sungai Banjir Kanal Timur (lihat Gambar 2). Luas permukiman nelayan Tambak Mulyo adalah $\pm 45,29$ Ha dengan area tambak/kolam ikan sebesar 10, 89 Ha dan area permukiman seluas 34,4 Ha. Lokasi kawasan permukiman nelayan di Tambakmulyo sangat ideal jika dilihat dari kepentingan nelayan, karena berada di antara dua muara sungai, tempat ikan bersarang. Pada waktu musim Barat; musim angin kencang yang disertai hujan dan badai yang berlangsung selama lebih kurang tiga bulan setiap tahunnya; nelayan dapat menambatkan kapal-kapalnya di tepian kedua sungai untuk berlindung dari terpaan ombak yang ganas. Selama masa tunggu untuk dapat melaut, mereka melakukan kegiatan memperbaiki kapal 
dan merawat jala/jaring yang dilakukan di bantaran sungai. Kegiatan inilah yang memicu awal munculnya ruang perkotaan di kawasan permukiman nelayan.

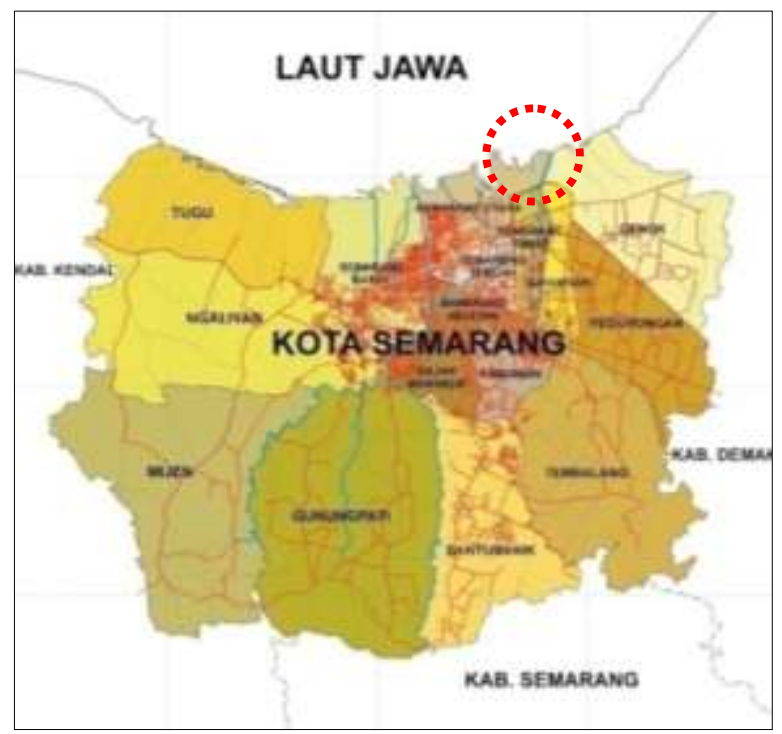

Gambar 1. Peta wilayah Kota Semarang

Sumber: Bappeda Kota Semarang

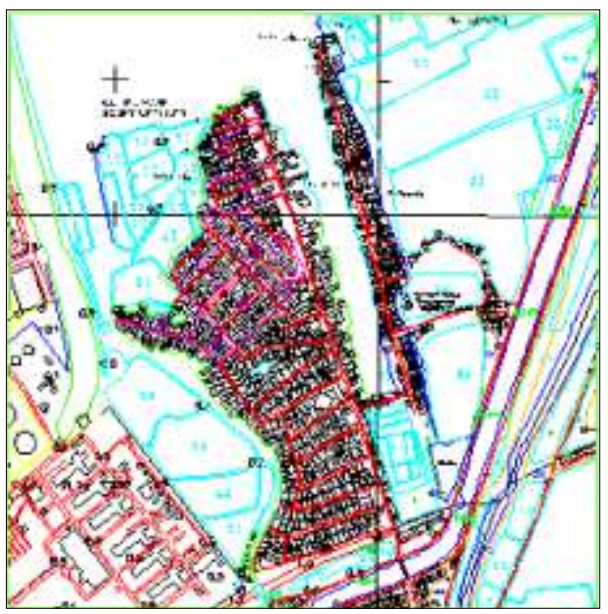

Gambar 2. Lokus penelitian

Pada saat ini kondisi fisik lingkungan pemukiman nelayan Tambakmulyo sangat tidak memadai. Sudah hampir satu dekade kawasan ini selalu dilanda bajir air pasang/ rob. Kawasan terbangunnya sebagian besar terdiri dari bangunan temporer dengan angka kepadatan bangunan sangat tinggi. Fasilitas lingkungan seperti jalan, selokan, jamban umum dan sanitasi lingkungan, serta ruang terbuka boleh dikatakan sangat minim. Di 
kawasan permukiman ini juga tidak memiliki fasilitas untuk kegiatan nelayan yang memadai. Sebagian besar fasilitas nelayan seperti dermaga, bangunan tempat pelelangan ikan, pasar ikan, pasar tradisional berkondisi buruk dan kapasitasnya sudah tidak lagi mencukupi. Di kawasan permukiman nelayan Tambakmulyo terdapat beberapa fasilitas nelayan antara lain seperti: 1) tempat perapatan perahu; 2) pusat pendaratan ikan; 3). Bangunan tempat pelelangan ikan; 4) pasar ikan dan pasar tradisional; 5) bengkel perahu; 6) tempat penjualan solar; 7) industri rumah tangga pengolahan ikan dan pengasapan ikan.

Dimulai pada dekade tahun 60-an, terjadi migrasi nelayan dari daerah lain pindah ke kawasan permukiman nelayan Tambakmulyo. Angka migrasi ini bertambah tinggi sejak kota Semarang mengalami pemekaran wilayah pada tahun 1977. Luas wilayah administrasi kota Semarang meningkat hampir tiga kali lipatnya. Anehnya luas kawasan permukiman nelayan relatif tidak bertambah, namun mengalami perkembangan interstisial (perkembangan kearah dalam) (Zahnd, 1999). Kawasan sisi Timur sungai banjir kanal Timur dahulu merupakan daerah Kabupaten Demak, semenjak pemekaran wilayah menjadi daerah administrasi kota Semarang. Pada masa awal pertumbuhannya permukiman nelayan tumbuh secara alami, sebagian berpola linier dan berorientasi ke laut berkonsep waterfront. Pada tahun 1990-an, alur dua sungai tersebut di pindahkan ke arah Timur, karena alasan tingginya sedimentasi flivial di kedua sungai sehingga menyebabkan pendangkalan di kolam pelabuhan Tanjung Emas. Sekarang, muara dua sungai lama berubah menjadi "kali mati" yang airnya tercemar karena tidak mengalir dan dimanfaatkan sebagai tempat pembuangan sampah dan jamban (lihat Gambar 3). Lokasi ruang perkotan di kawasan ini berubah, dari semula berorientasi ke sungai dan laut, berpindah ke lokasi yang mempunyai akses langsung ke jalan lingkungan permukiman.

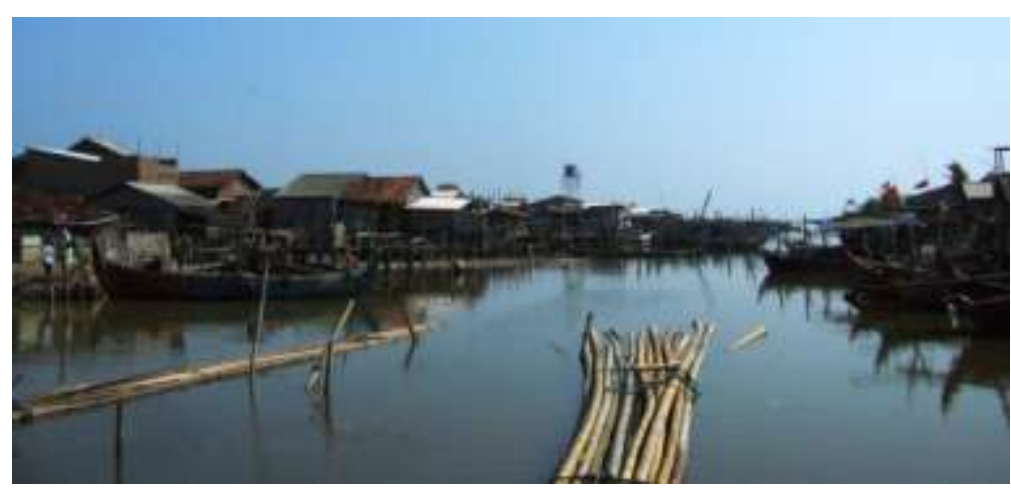

Sumber: Survey Lapangan 2012

Gambar 3. Panorama kali mati

Migrasi penduduk dari daerah lain ke kawasan permukiman nelayan Tambakmulyo menambah kompleksitas permasalah sosial, karena para migrant kebanyakan bermata pencaharian non nelayan, yaitu sebagai buruh, pedagang dan karyawan. Hal ini disebabkan tumbuhnya industri dan pabrik baru berlokasi disekitarnya. Kebutuhan akan ruang perkotaan yang mampu mewadahi kegiatan sosial sesuai dengan kultur dan adat segmen masyarakat pendatang, berbeda dengan kebanyakan nelayan yang telah eksis sebelumnya. Oleh karena itu perlu dilakukan kajian mendalam tentang transformasi ruang perkotaan di 
kawasan permukiman nelayan Tambakmulyo, untuk mencari solusi dan bentuk intervensi dan pengendalian penggunaan ruang yang tepat.

Dalam proses pertumbuhan dan perkembangan kota, perubahan ruang perkotaan selalu terjadi. Menemukenali transformasi ruang perkotaan pada suatu entitas yang khas dapat mengungkap gambaran utuh latar belakang kausalnya. Ruang perkotaan adalah urban artefact (peninggalan kawasan perkotaan) hasil sebuah proses sosial. Dengan demikian, bentukan berupa ruang perkotaan hanya bisa dipahami dalam konteks sosio spasialnya. Ruang perkotaan, tidak akan muncul secara tiba tiba, karena merupakan produk dari sebuah rangkaian proses sosial yang kompleks.

Ruang perkotaan di permukiman nelayan Tambakmulyo mengalami transformasi menyesuaikan terhadap perubahan kebiasaan dan adat istiadat pelaku ruangnya sekaligus merupakan salah satu strategi survival terhadap ancaman perubahan lingkungan alam disekitarnya.

Perubahan kebiasaan dari para pelaku ruang dan adaptasi terhadap perubahan lingkungan alam berdampak pada terjadinya transformasi ruang perkotaan di permukiman nelayan Tambakmulyo Semarang.

Permasalahan penelitian di atas dapat dirumuskan menjadi pertanyaan penelitian sebagai berikut: Bagaimana fenomena transformasi ruang perkotaan di permukiman nelayan Tambakmulyo, di kawasan pantai Kota Semarang?

Penelitian ini bertujuan untuk mendapatkan pemahaman yang lebih dalam tentang fenomena transformasi ruang perkotaan di permukiman nelayan baik dilihat dari aspek fisikalnya maupun dari perspektif sosio-spasialnya. Dengan memahami fenomena tersebut, maka rekomendasi untuk mengakomodasikan tranformasi tersebut dapat diberikan, baik dalam bentuk rekomendasi penelitian lebih lanjut maupun rekomendasi kebijakan yang perlu dilakukan oleh Pemerintah Kota Semarang.

\section{Metode Penelitian}

Dalam domain ilmu perencanaan dan perancangan kota telah banyak teori yang mengupas tema urban space and spatial (ruang dan spasial perkotaan), yang merupakan hasil olah pikir para pakar perkotaan yang bersifat rigorous. Dengan demikian rumpun teori tersebut dapat dipakai sebagai frame work (kerangka pikir) untuk mendukung penelitian ini. Karena penelitian ini diawali dengan kajian pustaka, oleh karenanya dapat dikategorikan sebagai theory verification research (penelitian verifikasi teoritis), dengan menggunakan pendekatan deduktif - rationalistik (Muhadjir, 2007). Sedangkan metode yang dirasa tepat untuk dapat mengungkap fenomena tranformasi ruang perkotaan adalah deskriptif kualitatif (Newman, I and Benz, C.R., 1998).

Untuk dapat mempertinggi tingkat validitas data lapangan, analisa data spasial dilakukan dengan cara memanfaatkan peta digital dan citra satelit. Sedangkan kebutuhan informasi dalam bentuk discrete phenomena dicari dengan cara melakukan observasi dan survey lapangan. Langkah selanjutnya adalah melakukan in-depth interview sebagai upaya untuk enrichment (pengkayaan) informasi yang telah didapatkan sebelumnya. Langkah langkah tersebut diperlukan karena penelitian tentang fenomena perkotaan tidaklah cukup dengan hanya melihat kondisi fisikalnya saja namun diperlukan upaya inovatif dalam mendalami dimensi sosio-spasialnya. 
Temuan penelitian dengan metode deskriptif kualitatif ini kemudian diverifikasi dengan sekelompok variabel hasil dari kajian teori yang telah dilakukan sebelumnya.

\section{Analisis Ruang Perkotaan di Permukiman Nelayan di Tambakmulyo Semarang}

Kota akan selalu tumbuh dan berkembang, walaupun perencanaan kotanya dan prediksi yang dilakukan sebelumnya sudah cermat. Pertumbuhan dan perkembangan kota disebabkan karena proses inhabitasi penduduknya (Kirkman dkk, 2007; Kostof, 1991). Pertumbuhan dan perkembangan kota akan berpengaruh pada bentuk fisik dan konfigurasi ruang perkotaannya. Dengan demikian konfigurasi ruang perkotaan akan selalu berubah dan tidak pernah berhenti selama berlangsungnya proses pertumbuhan kota. Ruang perkotaan merupakan bagian dari sebuah kawasan terbangun yang berperan sebagai container (wadah) dari berbagai kegiatan yang berlangsung pada seting permukiman tertentu (Doxiadis, 1981; Rapoport, 1977). Apabila terjadi perubahan pola perilaku dan eksisting kulturnya, akan berkorelasi dengan perubahan distribusi teritorialnya, demikian pula sebaliknya (Mills, 2012; Pipkin, 1981). Fenomena perubahan konfigurasi ruang perkotaan hanya bisa dipahami dalam konteks sosio spasialnya (Mills, 2012; Madanipour, 1996).

Dalam memahami makna tempat place (tempat) dan space (ruang) diperlukan pemahaman akan dua aspek yang saling berkait yaitu: 1) kumpulan berbagai bangunan dan artefak ( $a$ collection of building and artifacts) dan 2) tempat untuk menjalin relasi sosial ( $a$ site for social relationships). Madanipour menambahkan bahwa dalam memahami makna sebuah ruang perkotaan, tidak hanya membicarakan dimensi fisik, namun juga dimensi sosial, dan simbolisnya secara interaktif.

Sementara itu Rossi (1982) dan Lin (2007) mengatakan bahwa kota merupakan kumpulan koleksi artefak bersejarah. Menjadi suatu keharusan jika akan mempelajari sebuah fenomena kota langkah awalnya adalah melakukan historical reading dilanjutkan dengan analisa urban tissue. Ada dua pendekatan untuk memahami kota sebagai sebuah proses sejarah, yaitu: 1) sebagai material artifact, berupa objek buatan manusia yang meninggalkan jejak, dan artefak yang menjadi teks sejarah (historical text); dan 2) sebagai collective imagination, kota dilihat sebagai sintesis dari rangkaian nilai-nilai.

Berdasar pada deskripsi tentang ruang perkotaan seperti telah disebutkan diatas, arsitektur perkotaan mempunyai kesempatan untuk memberikan kontribusi pemikiran melalui pembelajaran terhadap ruang perkotaan yang ada. Ilmu perancangan kota sudah seharusnya tidak diartikan secara sempit sebagai proses teknis rancang bangun semata, juga terlalu naif jika hanya diartikan sebagai hasil cetusan idee dan proses kreatif. Ditambahkan oleh Lynch (1981), perancangan kota harus mempunyai perspektif luas dengan demikian sudah seharusnyalah mengggunakan konsep broad approach. Pada hakekatnya perancangan kota adalah sebuah proses pembentukan ruang sosial.

Ruang perkotaan sebagai hasil artikulasi masyarakatnya dapat dilihat sebagai sebuah produk dari sebuah rangkaian proses sosial yang kompleks. Dapat dipahami bahwa ruang perkotaan tidak akan muncul secara tiba tiba, karena terbentuk dari hasil perjalanan sebuah proses sejarah. Dengan demikian perubahan konfigurasi ruang perkotaan hanya bisa dipahami dalam konteks sosio spasialnya (Madanipour, 1996). 
Berdasarkan pada kajian diatas dapatlah ditarik sebuah kesimpulan bahwa ruang perkotaan seharusnya dilihat sebagai sebuah proses dan sebagai sebuah produk. Dalam domain perancangan kota ruang perkotaan mempunyai dimensi fisikal dan dimensi sosio spasial serta dimensi temporal (Carmona. et al., 2006).

Analisis ruang perkotaan yang akan dilakukan di permukiman nelayan Tambakmulyo meliputi tiga aspek, yaitu 1) dimensi fisikal, 2) dimensi sosio spasial dan 3) dimensi temporal.

\section{Dimensi fisik ruang perkotaan di permukiman nelayan Tambakmulyo}

Pembahasan terkait dengan dimensi fisik terdiri dari dua aspek besar yaitu: fisik kawasan itu sendiri dan struktur kawasan.

\section{a. Fisik kawasan permukiman nelayan}

Pada awal terbentuknya kawasan permukiman nelayan di Tambakmulyo, kawasan tersebut masih berupa tebaran bangunan rumah semi permanen terletak disepanjang muara sungai berpola un-planned settlement (lihat Gambar 4).

Sumber: Setioko.et.al., 2012

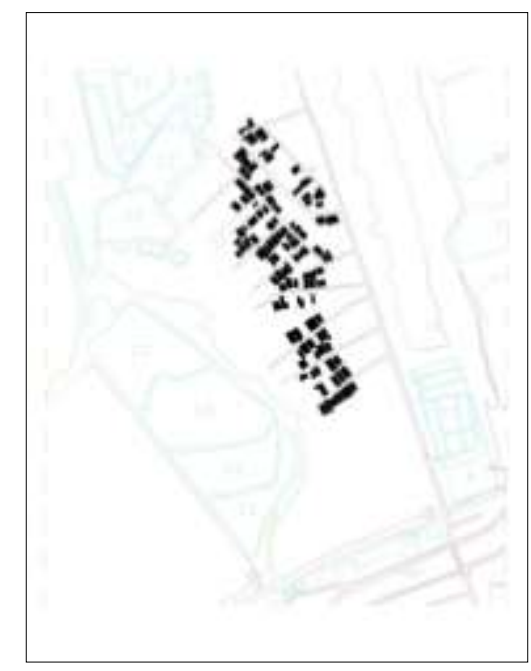

Gambar 4. Peta Hipotetis sebaran bangunan rumah pada awal terbentuknya permukiman nelayan.

Jalan setapak pararel dengan sungai merupakan jalan lingkungan hanya digunakan sebagai penghubung antar rumah. Pada umumnya bangunan rumah mempunyai double access. Bagian depan rumah berorientasi ke sungai dan bagian belakang dapat dicapai dari jalan setapak. Sungai merupakan jalur transportasi utama untuk menuju ke laut maupun untuk menuju ke daratan/ kota Semarang, tempat dimana para nelayan menjual hasil tangkapan ikan. Secara alami ruang perkotaan terbentuk di sepanjang bantaran / pinggiran sungai karena berperan mewadahi kegiatan masyarakat nelayan yang mencerminkan pola perilaku dan adatnya. 
Kegiatan yang berlangsung di ruang perkotaan ini masih didominasi oleh kegiatan produksi dan perdagangan antara lain kegiatan nelayan menjual hasil laut, perbaikan kapal dan jaring ikan serta pengeringan ikan/hasil laut.

Pada tahun 1980-an sebagian kawasan permukiman nelayan termasuk dalam cakupan program perbaikan kampung (KIP). Karena proyek berskala nasional, kebijakan dan prosedur yang diimplementasikan pada perbaikan permukiman nelayan sama dengan permukiman kampung kota pada umumnya. Proses ini diperumit dengan ketidak jelasan kepemilikan lahan. Ruang terbuka publik yang sering digunakan sebagai ruang perkotaan menjadi terpecah pecah karena tersegregasi oleh jalan setapak. Pola permukiman nelayan Tambakmulyo menjadi berpola planned settlement (lihat Gambar 5).

Sumber: Setioko.et.al., 2012

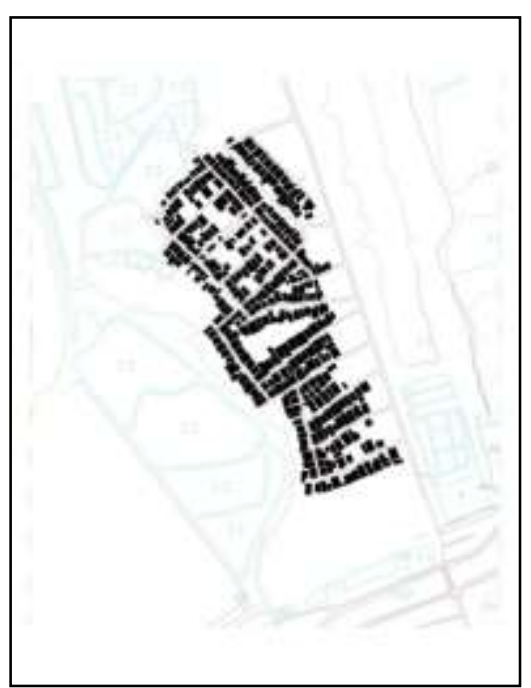

Gambar 5. Figure Ground tahun 1980

Tingginya sedimentasi sungai Banjir Kanal Timur dan Kali Banger mengganggu akses kapal menuju ke daratan. Sungai sudah tidak mungkin lagi dipakai sebagai jalur transportasi utama. Peran sungai digantikan dengan jalur transpotasi darat berupa jalan. Orientasi rumah di permukiman nelayan pada umumnya berubah kearah jalan. Pada masa awal terbentuknya kawasan permukiman nelayan ruang antara bangunan rumah dan sungai dimanfaatkan sebagai halaman depan. Dengan berubahnya orientasi bangunan rumah ruang antara ini berubah perannya menjadi halaman belakang.

Lambat laun peran ruang perkotaan di tepian sungai menjadi hilang, digantikan dengan terbentuknya ruang perkotaan baru mengandalkan jalur asesibilitas baru berupa jalan. Pada tahun 1970 pemerintah kota membangun bangunan Tempat Pelelangan Ikan, sebagai upaya untuk mewadahi kegiatan para pedagang ikan yang berjualan disepanjang tepian sungai. Tempat Pelelangan Ikan ini juga berperan sebaga tempat bertemunya nelayan dengan para pedagang grosier.

Karena tingginya sedimentasi di sungai Banjir Kanal Timur dan Kali Banger menyebabkan dangkalnya kolam pelabuhan Tanjung Mas, pada tahun 1990-an dilakukan 
perubahan alur sungai. Dua muara sungai digeser ke arah Timur, menyebabkan muara sungai lama menjadi kali mati. Area ini sekarang menjadi tempat bongkar muat hasil laut, dermaga dan parkir kapal serta jamban permukiman penduduk. Meningkatnya jumlah migran baik nelayan maupun non nelayan yang bermukim di kawasan ini, menyebabkan bantaran sungai terokupasi menjadi permukiman yang padat dan kumuh (lihat Gambar 6 dan 7).

Sumber: Setioko.et.al., 2012

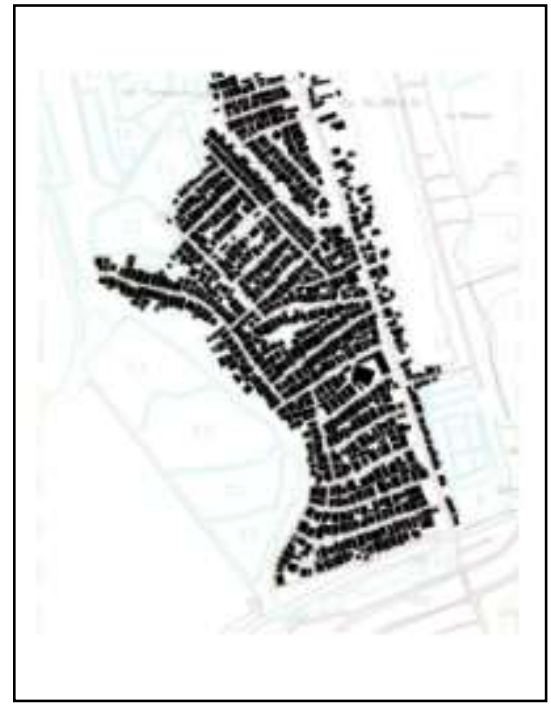

Gambar 6. Figure Ground tahun 2010

\section{b. Struktur kawasan permukiman nelayan}

Pada masa awal pertumbuhan kawasan permukiman nelayan Tambakmulyo, pola permukimannya berbentuk organik bertebaran di sepanjang sungai dan muara sungai Banjir Kanal Timur dan Kali Banger. Kegiatan masyarakat nelayan berlangsung di tepian sungai memanfaatkan ruang terbuka yang terbentuk diantara deretan rumah dan sungai. Distribusi spasial kawasan permukimannya memadat di tepian sungai dan pantai sedikit longgar di tengah dataran. Belum terjadi fragmentasi ruang permukiman dilihat dari tingkat sosial dan tipologi masyarakatnya.

Dengan semakin meningkatnya jumlah nelayan yang tinggal akibat migrasi dari daerah lain, dan meningkatnya produksi hasil tangkapan ikan, mulailah terjadi transaksi perdagangan antara nelayan dan para tengkulak. Aktivitas pembongkaran dan perdagangan hasil laut ini berlangsung secara sporadis di ruang terbuka di sepanjang sungai. Kegiatan ini berlangsung pertama kali pada pagi pagi buta dan sekali lagi di siang hari. Pada masa jeda antara dua kegiatan perdagangan, ruang terbuka ini dimanfatkan untuk memperbaiki jala dan perlengkapan melaut serta sebagai ajang komunikasi sosial masyarakat nelayan. Berawal dari fenomena tersebut terbentuklah ruang perkotaan di permukiman nelayan Tambakmulyo (Bertaud, 2003). Sebagai konsekuensi dari semakin banyaknya bangunan rumah penduduk, kawasan tersebut tumbuh dengan pola ribbon development. Semakin lama deretan rumah nelayan semakin panjang. Pada waktu itu belum terbentuk pusat lingkungan permukiman. Kebutuhan hidup sehari hari di dapatkan dari pasar kota (lihat Gambar 8).. 


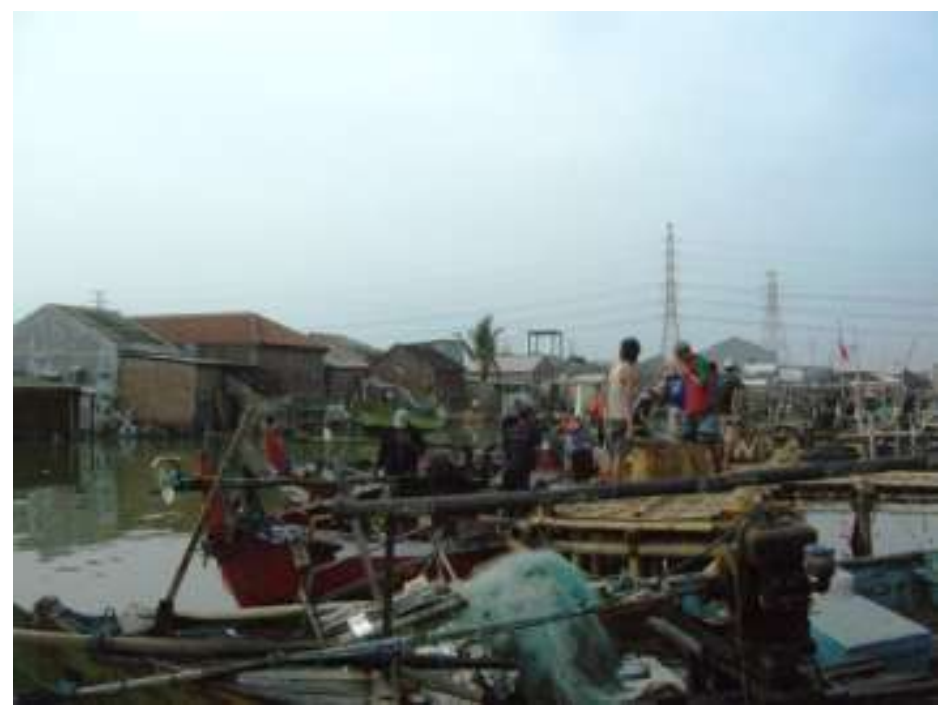

Gambar 7: Kali Mati dimanfaatkan sebagai lokasi bongkar muat hasil laut.
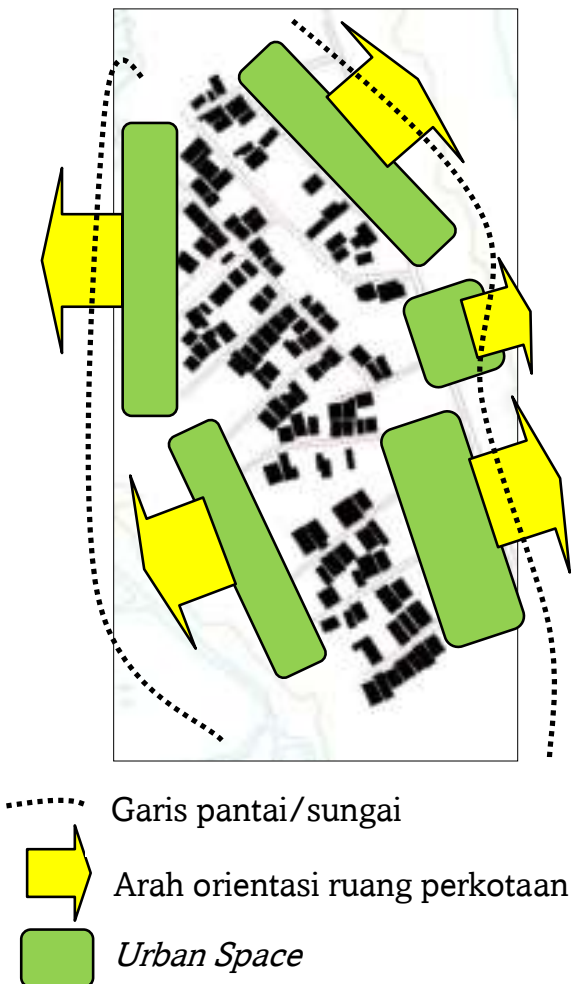

Garis pantai/sungai

Arah orientasi ruang perkotaan

Urban Space

Sumber: Analisa Peneliti

Gambar 8: Struktur kawasan pada awal terbentuknya permukiman nelayan. 
Dengan semakin meningkatnya jumlah pedagang ikan dan hasil laut, pemerintah kota Semarang membangun bangunan permanen menyerupai barak terbuka untuk digunakan sebagai tempat pelelangan ikan. Bangunan tempat pelelangan ikan ini berada di tepi jalur jalan utama menuju pusat kota. Untuk membongkar hasil laut, kapal nelayan bersandar di dermaga yang dibangun berdekatan dengan tempat pelelangan ikan. Hasil laut kemudian diangkut ke tempat pelelangan ikan lewat jalan khusus. Pembangunan tempat pelelangan ikan ini mempunyai dua tujuan, yang pertama adalah menyediakan fasiltas jual beli hasil laut bagi para nelayan dan pedagang besar, dan yang kedua memungut restribusi dari perdagangan grosier melalui cara pelelangan. Pembangunan tempat pelelangan ikan menimbulkan efek berantai berupa munculnya kegiatan ikutan lain, berupa perdagangan skala kecil yang dilakukan dipasar ikan tradisional.

Pada era tersebut struktur kawasan permukiman nelayan di Tambakmulyo berpusat di area sekitar tempat pelelangan ikan. Pusat kawasan ini semakin lengkap dengan dibangunnya pasar ikan, menyusul kemudian bangunan tempat ibadah dan sekolah. Lambat laun area ini tumbuh menjadi center of grafity (pusat daya tarik) bagi kawasan permukiman nelayan (Setioko.et.al., 2012). Kawasan ini tumbuh menjadi ruang perkotaan utama, dimana kegiatan berskala cukup besar sering dilakukan (lihat Gambar 9).

Source: Setioko.et al., 2012

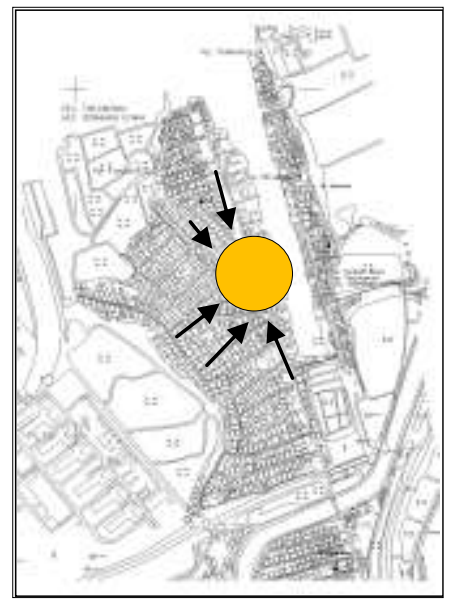

Gambar 9. Pusat Daya Tarik

Pusat daya tarik kawasan tidak hanya menjadi daya tarik bagi penduduk dari luar kawasan untuk tinggal dan bermukim di kawasan ini, tetapi juga menjadi daya dorong keluarnya berbagai kegiatan yang bernuansa nelayan ke luar kawasan. Kawasan pusat daya tarik menjadi pendorong terjadinya berbagai kegiatan perkotaan yang tidak berkaitan dengan kegiatan para nelayan. Pembangunan sarana umum di kawasan ini yang dimaksudkan untuk memenuhi kebutuhan nelayan, telah menjadi pendorong terjadinya kegiatan perkotaan, seperti halnya di kawasan perkotaan pada umumnya.

Sebelum pusat daya tarik terbentuk di sekitar lokasi tempat pelelangan ikan dan pasar ikan serta pasar tradisional, pola pergerakan penduduk berciri polysentris, mengarah ke ruang perkotaan yang tersebar secara sporadis. Namun dengan terbentuknya pusat daya tarik skala lingkungan pola polysentris berubah menjadi monosentris. Dengan terfragmentasinya permukiman penduduk menjadi dua zoning utama, yaitu zoning permukiman nelayan di bagian Utara dan zoning permukiman non nelayan di bagian Selatan, pola pergerakan penduduk secara perlahan lahan kembali berubah menjadi 
polysentris, namun dengan skala yang berbeda jika diperbandingkan dengan pada awal masa pembentukannya.

Karena sebagian besar bangunan rumah berorientasi ke daratan ruang perkotaan berskala pelayanan kecil tumbuh di lokasi lokasi yang mudah dicapai dari jalan lingkungan. Peran ruang kota di tepian sungai menyurut, sedangkan peran ruang kota di sepanjang jalan meningkat. Tepian sungai berubah menjadi halaman belakang. Berakhirlah citra water front di kawasan nelayan Tambakmulyo.

\section{Dimensi Sosio Spasial ruang perkotaan di permukiman nelayan Tambakmulyo}

Kawasan terbangun merupakan container (wadah) kegiatan yang berlangsung pada seting permukiman (Doxiadis, 1981; Rapoport, 1977). Apabila terjadi perubahan pada distribusi teritorialnya akan berkorelasi dengan perubahan pola perilaku dan eksisting kulturnya, demikian pula sebaliknya (Pipkin, 1981). Pada awal terbentuknya kawasan permukiman nelayan, bangunan rumah masih sedikit dengan demikian ruang terbukanya masih sangat luas. Ruang antara deretan bangunan rumah dan sungai/pantai merupakan "premium areas" untuk dimanfaatkan kecuali sebagai ruang produksi juga sebagai ruang kegiatan sosial. Karena pelaku ruang seluruhnya adalah entitas nelayan, dapat diduga kegiatan yang dilakukannya khas nelayan. Pesat tumbuh dan berkembang infrastruktur jalan di kawasan permukiman ini menyebabkan penggunaan moda transportasi sungai terabaikan. Jalan darat mempunyai asesibilitas lebih tinggi menuju ke semua lokasi di kota Semarang, dibandingkan dengan transportasi lewat sungai.

Era sungai sebagai jalur transportasi utama berakhir, perannya digantikan jalan darat. Perubahan orientasi permukiman nelayan Tambakmulyo dari menghadap sungai berubah menjadi menghadap jalan merupakan upaya adaptasi sebagai respon adanya perubahan lingkungan fisiknya. Kegiatan sosial masyarakat nelayan lebih banyak terjadi di ruang perkotaan yang mudah diakses dari jalan, tidak lagi di pinggir sungai. Ruang perkotaan di pinggir jalan menjadi kawasan primer yang diminati banyak orang, sedangkan ruang di pinggir sungai berobah menjadi kawasan sekunder menjadi ruang yang terabaikan. Pembangunan tempat pelelangan ikan diikuti dengan pembangunan pasar ikan dan pasar tradisional, di area yang mempunyai asesibilitas bagus baik dari jalan maupun sungai. Dikemudian hari ruang ini tumbuh menjadi ruang perkotaan dan pusat lingkungan permukiman nelayan Tambakmulyo. Struktur kawasan berobah, baik pada skala mikro, meso maupun makro. Pengamatan atas fenomena sosial yang terjadi di lokus penelitian sejak dari awal terjadinya bentukan permukiman nelayan sampai sekarang, secara jelas memperlihatkan adanya perubahan pola perilaku masyarakatnya dipicu karena adanya perubahan distribusi teritorialnya.

Meningkatnya asessibilitas dan mobilitas penduduk berimplikasi pada homogenitas warga penghuni kampung Tambakmulyo. Pada dekade 1970-an kawasan disekitarnya tumbuh dan berkembang menjadi kawasan industri, pergudangan dan pelabuhan. Perubahan penggunaan lahan skala kota menjadi pemicu migrasi penduduk dari daerah lain untuk bertempat tinggal di kawasan ini. Pendatang baru tidak terbatas bermata pencaharian sebagai nelayan, namun banyak yang bermata pencaharian non nelayan, antara lain sebagi buruh pelabuhan, buruh pabrik dan karyawan. Kegiatan, kebiasaan, adat dan kultur kaum pendatang baru sama sekali berbeda dengan entitas nelayan. Ritme hidup kesehariannyapun sangat berbeda. Nelayan tradisional biasanya berangkat melaut pada 
malam hari dan pulang dari menangkap ikan pada pagi pagi buta atau siang hari, karena memanfaatkan angin darat dan angin laut. Meskipun sekarang perahu nelayan pada umumnya sudah menggunakan motor penggerak baling baling, tidak lagi menggunakan layar, ritme ini tetap saja berjalan. Kehidupan ruang perkotaan disekitar tempat pelelangan ikan mulai menggeliat sejak jam 03.00 pagi, ditandai dengan kedatangan kapal nelayan untuk merapat di dermaga kali mati untuk membongkar ikan dan hasil laut lainnya. Gelombang kedua kedatangan kapal para nelayan pada siang hari. Jeda waktu kegiatan nelayan di ruang perkotaan biasanya dimanfaatkan untuk kegiatan sosial. Rutinitas kerja nelayan berlanjut terus tanpa mengenal libur mingguan. Jika musim angin kencang datang, barulah mereka gunakan untuk libur. Ritme kaum pendatang non nelayan, yang populasinya semakin lama semakin banyak, berbeda dengan ritme kehidupan nelayan. Berangkat pagi dan pulang sore adalah ritme keseharian mereka. Minggu merupakan hari libur. Perbedaan ritme kehidupan antar dua entitas yang berbeda ini menghalangi terjadinya kontak sosial, dan akhirnya mempersulit terbangunnya solidaritas sosial. Meskipun belum pernah terjadi konflik sosial antar dua entitas ini, bukan tidak mungkin ritme kehidupan ini merupakan salah satu embrionya.

Urbanisasi berlebih pada dekade 2000-an, menyebabkan sisi Timur Kali Mati juga dipadati permukiman campuran. Secara garis besar sebaran tipologi warga di kawasan Tambakmulyo bagian Utara, tepi kali mati dan pantai, dihuni mayoritas oleh para nelayan. Sedangkan di bagian Selatan dan bagian tengah dihuni oleh non nelayan. Entitas nelayan sendiri terbagi menjadi 3 (tiga) tipologi, yaitu; 1) nelayan penangkap ikan, 2) nelayan pekerja bagan, dan 3) nelayan penyedia jasa sewa perahu. Sedangkan non nelayan terdiri dari: 1) Buruh, 2) Pegawai, 3) Pedagang. Masing masing entitas cenderung hidup berkelompok menyebabkan zonasi kawasan permukiman nelayan menjadi terpecah pecah.

Sudah hampir satu dekade kawasan permukiman nelayan Tambakmulyo dilanda genangan "rob" (banjir air pasang laut). Area genangannya semakin lama semakin luas dan permukaan airnya semakin tinggi. Pemerintah kota Semarang pada tahun 2010, dengan dilatar belakangi alasan rob yang selalu menggenangi bangunan tempat pelelangan ikan, lokasi lama ditutup dan dibangun bangunan baru pada lokasi yang bebas dari rob. Namun letaknya terpencil, jauh dari permukiman nelayan. Sejak berdiri hingga sekarang bangunan tempat pelelangan ikan tersebut tidak pernah dimanfaatkan, baik oleh nelayan maupun oleh para pedagang ikan. Aktivitas pelelangan ikan terhenti. Kegiatan warga di ruang perkotaan di sekitar bangunan pasar dan tempat pelelangan ikan menurun drastis. Nelayan menjual hasil laut langsung ke tengkulak. Transaksi ini berlangsung di bantaran sungai kali mati yang sangat kumuh dan sempit. Baru pada tahun 2012, aktivitas pelelangan ikan dimulai lagi bertempat di bangunan lama, dan aktivitas perdagangan dan kegiatan sosial warga secara bernagsur pulih. Ilustrasi tersebut menunjukkan bahwa struktur sosio spasial yang sudah terbentuk dengan pusat aktivitasnya adalah bangunan pelelangan ikan, tidak demikian mudah untuk dirobah. Ruang perkotaan yang telah terbentuk lebih dari 30 tahun sudah menjadi "spatial simbolic system”(Setioko, et al., 2012).

\section{Dimensi temporal ruang perkotaan di permukiman nelayan Tambakmulyo}

Eksistensi permukiman nelayan Tambakmulyo dimulai pada tahun 1950-an, sebagai sebuah perkampungan nelayan berskala kecil, dengan lokasi terpencil, sulit 
dijangkau dari pusat kota Semarang. Kegiatan penduduknya yang semuanya nelayan sebatas menangkap ikan di laut dan menjual hasilnya langsung ke pasar Johar dengan memanfaatkan kali Banger sebagai jalur transportasi utama. Boleh dikatakan permukiman nelayan Tambakmulyo hanya digunakan sebagai tempat istirahat dan tempat menambat dan memperbaiki kapal pada waktu musim Barat datang.

Dengan semakin meningkatnya jumlah nelayan, aktivitas penduduknya mulai beragam, seperti kegiatan berdagang komoditas hasil laut dan kegiatan produksi, antara lain pengeringan ikan asin serta pengasapan ikan. Tingginya sedimentasi menyebabkan mengecilnya peran sungai sebagai sarana transportasi utama menuju kota. Peran sungai sebagai jalur transportasi mengecil dan peran jalan darat semakin menguat. Perubahan penggunaan moda transportasi ini tidak saja mempengaruhi struktur kawasan tetapi juga berdampak pada distribusi spasial ruang perkotaan. Time cycle (siklus waktu) kegiatan masyarakat nelayan berubah secara mencolok, demikian pula frekuensinya meningkat dengan tajam, karena tidak lagi tergantung dan terpengaruh oleh cuaca dan iklim. Fluktuasi kegiatan nelayan di ruang perkotaan pada awalnya memuncak pada waktu berlangsungnya pembongkaran hasil laut kemudian diikuti dengan kegiatan pelelangan /perdagangan ikan. Semakin lama fluktuasi kegiatannya semakin merata sepanjang hari. Jeda waktu pemanfaatan ruang perkotaan semula diisi dengan kegiatan khas nelayan, seperti memperbaiki jaring/ jala, perbaikan kapal sudah tidak lagi terlihat mencolok. Tersaingi dengan kegiatan sosial non nelayan yang lain. Ditambah dengan semakin mengecilnya dimensi ruang perkotaan yang ada; karena tingginya angka kepadatan bangunannya; aktivitas khas nelayan tidak lagi bebas berlangsung di lahan terbuka di ruang ruang perkotaan.

Perubahan siklus waktu mempengaruhi time management (pengelolaan waktu) penggunaan ruang perkotaan oleh masyarakat (Carmona, et al., 2006). Pada awalnya ruang perkotaan di kawasan permukiman nelayan Tambakmulyo beciri mono-functional (fungsi tunggal) cenderung berubah menjadi fungsi mixed uses (kegiatan campuran). Pergeseran dominasi kegiatan berciri spesifik di ruang perkotaan secara teoritik diakibatkan oleh adanya perubahan konfigurasi spasial tata guna lahannya. Namun fenomena di kawasan permukiman nelayan Tambakmulyo lebih cenderung disebabkan oleh adanya perubahan siklus waktu dan pengelolaan waktu.

\section{Kesimpulan}

Tranformasi ruang perkotaan di permukiman nelayan kampung Tambakmulyo Semarang terjadi pada dimensi fisikalnya, dimensi sosio-spasialnya dan juga dimensi temporalnya. Berikut ini adalah beberapa rincian kesimpulan yang dapat diambil dari penelitian ini:

1. Transformasi fisik

a. Lokasi ruang perkotaan bergeser dari tepi/pinggiran sungai menjadi ke daratan.

b. Terjadi perubahan orientasi ruang, awal terbentuknya berorientasi ke sungai laut kemudian berobah menjadi berorientasi ke daratan.

c. Enclosure ruang pada awalnya imaginer (tepian sungai dan pantai) sekarang menjadi lebih jelas dan tangible (diantara bangunan dan jalan). 
d. Meningkatnya kepadatan bangunan dan minimnya ruang terbuka, memaksa warga memanfaatkan ruang terbuka beraksesibilitas tinggi meskipun dimensinya kecil sebagai wadah kegiatan sosial.

e. Teritorialitas ruang perkotaan semakin lama bergeser dari ruang milik bersama ke lahan milik pribadi.

2. Transformasi sosio-spasial

a. Pelaku ruang pada awal terbentuknya permukiman nelayan hanya terdiri dari entitas nelayan saja. Lambat laun tipologi masyarakatnya menjadi semakin heterogen.

b. Kegiatan yang diwadahi dalam ruang perkotaan pada awalnya berciri unik khas nelayan, berobah menjadi berbagai kegiatan yang tidak spesifik.

c. Dalam rentang waktu 5 dekade sejak tahun 1970an telah terjadi fragmentasi zonasi hunian dan semakin bervariasinya tipologi penduduk.

d. Ruang perkotaan bertransformasi dari berciri dari non democratic space menjadi full democratic space dan dari ruang perkotaan menjadi ruang publik.

e. Publik Conciousness (kepedulian publik) pada ruang perkotaan dahulu lebih tinggi dibandingkan dengan sekarang.

3. Transformasi temporal

a. Perubahan "siklus waktu" dan "pengelolaan waktu" berkontribusi pada terjadinya transformasi fisik maupun transformasi sosio spasial kawasan permukiman nelayan di Tembakmulyo Semarang.

\section{Rekomendasi}

Merujuk dari kesimpulan hasil penelitian yang telah didapatkan beberapa hal penting dapat direkomendasikan, yaitu:

a. Bagi penelitian lanjutan

Penelitian tentang obyek kawasan dengan kehidupan sosial masyarakatnya yang unik belum banyak dilakukan. Harus diakui penelitian ini belum secara jelas mengungkap faktor penyebab terjadinya tranformasi ruang perkotaan. Oleh karenanya perlu ditindak lanjuti dengan serangkaian penelitian dengan obyek yang mirip, tetapi dengan fokus yang berbeda. Dengan demikian bisa dipakai sebagai rujukan dalam menyusun rencana pengembangan dan pengendalian penggunaan kawasan permukiman tanpa harus menghilangkan kebiasaan, adat dan kultur masyarakatnya.

b. Bagi Pemerintah Kota Semarang

Suatu kawasan yang unik seperti halnya permukiman nelayan seharusnya mendapatkan perhatian dan penanganan yang spesifik. Justifikasi empirik menunjukan bahwa pembangunan dan pengembangan kawasan permukiman dengan hanya menekankan pada aspek fisiknya saja, berpotensi menghilangkan kearifan lokal, budaya dan adat istiadat masyarakatnya yang telah berakar lama. Dengan demikian rencana pengembangan dan pemanfaatan kawasan permukiman seharusnya tidak hanya berdimensi fisik saja tetapi harus mempertimbangkan dimensi sosial budaya dan temporalnya.

\section{Daftar Pustaka}

Bappeda Kota Semarang dan Badan Pusat Statistik Kota Semarang. Kota Semarang Dalam Angka 2012.

Bertaud, A. Metropolis: the spatial organization of seven large cities. In: Sullivan, C. (ed). (2003). Time-Saver Standards for Urban Design. McGraw-Hill Companies, Inc. USA. 
Carmona, M., Heath, T., Taner, O., Tiesdel, S. (2006). Public Space - Urban Space. Architectural Press. USA.

Doxiadis, C.A. (1968). Ekistics: An Introduction to the Science of Human Settlements. Oxford University Press, New York.

Gür, Berin F. (2002) Spatialisation of Power/ Knowledge/ Discourse: Transformation of Urban Space Through Discursive Representations in Sultanahmet, Istanbul. Space and Culture; 2002; 5: 237.

Kirkman, Robert; Noonan, Douglas S; and Dunn, Sean K. (2012) Urban Transformation and Individual Responsibility: The Atlanta BeltLine. Planning Theory; 2012; 11: 418.

Kostof, S. (1991). The City Shaped Urban Patterns and Meanings through History. London: A Bulfinch Press Book Little Brown and Company.

Krier, R. (1991). Urban Space. Rizzoli International Publications, Inc. New York.

Lin, George C. S. (2007) Reproducing Spaces of Chinese Urbanisation: New City-based and Land-centred Urban Transformation. Urban Stud; 2007; 44: 1827.

Lynch, K. (1981). The Image of the City. MIT Press. Cambridge.

Madanipour, A. (1996). Design of Urban Space. An inquiry into a Socio - spatial Process. John Wiley \& Sons. England.

Mills, Amy. (2012). Urban Space and Social Transformation in the Middle East. Journal of Urban History; 2012; 38: 379 .

Muhadjir, H.N. (2007). Metodologi Keilmuan-Paradigma Kualitatif, Kuantitatif, dan Mixed. Rake Sarasin.Yogyakarta.

Newman, I and Benz.C.R. (1998). Southern Illinois University Press. USA.

Pipkin, J., Gory.M.L. (1981), Urban Social Space. Wadsworth Publishing Company. Belmont, California.

Rapoport, A. (1977). Human Aspects of Urban Form. Great Britain: Pergamon Press.

Rossi, A. (1984).The Architecture of the City. MIT Press.

Setioko, B., Pandelaki, E. E., dan Woro, M, T. (2012). Towards Sustainable Urban Growth: The Unaffected Fisherman Settlement Setting (with case study Semarang coastal area). Procedia Environmental Sciences Journal; Volume 17 / 2013. No ISSN: 1878 - 0296. Published by Elsevier.

Shirvani, H. (1985). The Urban Design Process. Van Nostrand Reinhold Company, Inc. USA.M., Heath, T., Taner, O., Tiesdel, S. (2003). Public Space - Urban Space. Architectural Press. USA.

Zahnd, M. (1999). Perancangan Kota secara terpadu - Teori perancangan kota dan penerapannya. Penerbit Kanisius. Yogyakarta. 